\title{
Influence of Sintering Temperature of Kaolin, Slag, and Fly Ash Geopolymers on the Microstructure, Phase Analysis, and Electrical Conductivity
}

\author{
Nur Nadiah Izzati Zulkifli 1,2, Mohd Mustafa Al Bakri Abdullah 1,2,*, Anna Przybył ${ }^{3}$ (D), Paweł Pietrusiewicz ${ }^{3}$ (D), \\ Mohd Arif Anuar Mohd Salleh 1,2, Ikmal Hakem Aziz 1,2 ${ }^{1}$, Dariusz Kwiatkowski ${ }^{4}$, Marcin Gacek ${ }^{3}$, \\ Marek Gucwa ${ }^{4}$ (D) and Jitrin Chaiprapa ${ }^{5}$
}

Citation: Zulkifli, N.N.I.; Abdullah, M.M.A.B.; Przybył, A.; Pietrusiewicz, P.; Salleh, M.A.A.M.; Aziz, I.H.; Kwiatkowski, D.;

Gacek, M.; Gucwa, M.; Chaiprapa, J. Influence of Sintering Temperature of Kaolin, Slag, and Fly Ash Geopolymers on the Microstructure, Phase Analysis, and Electrical Conductivity. Materials 2021, 14, 2213. https://doi.org/10.3390/ma14092213

Academic Editor: F. Pacheco Torgal

Received: 19 March 2021

Accepted: 20 April 2021

Published: 26 April 2021

Publisher's Note: MDPI stays neutra with regard to jurisdictional claims in published maps and institutional affiliations.

Copyright: (C) 2021 by the authors Licensee MDPI, Basel, Switzerland. This article is an open access article distributed under the terms and conditions of the Creative Commons Attribution (CC BY) license (https:/ / creativecommons.org/licenses/by/ $4.0 /)$.
1 Faculty of Chemical Engineering Technology, University Malaysia Perlis (UniMAP), Perlis 01000, Malaysia; nadiahizzati.zulkifli@gmail.com (N.N.I.Z.); arifanuar@unimap.edu.my (M.A.A.M.S.); ikmalhakem@unimap.edu.my (I.H.A.)

2 Geopolymer \& Green Technology, Center of Excellence (CEGeoGTech), University Malaysia Perlis (UniMAP), Perlis 01000, Malaysia

3 Department of Physics, Częstochowa University of Technology, Dabrowskiego 69, 42-201 Częstochowa, Poland; anna.przybyl@pcz.pl (A.P.); pawel.pietrusiewicz@pcz.pl (P.P.); marcin.gacek@pcz.pl (M.G.)

4 Faculty of Mechanical Engineering and Computer Science, Czestochowa University of Technology, Dabrowskiego 69, 42-201 Częstochowa, Poland; kwiatkowski@ipp.pcz.pl (D.K.); mgucwa@spaw.pcz.pl (M.G.)

5 Synchrotron Light Research Institute, Muang, Nakhon Ratchasima 30000, Thailand; jitrin@slri.or.th

* Correspondence: mustafa_albakri@unimap.edu.my

\begin{abstract}
This paper clarified the microstructural element distribution and electrical conductivity changes of kaolin, fly ash, and slag geopolymer at $900{ }^{\circ} \mathrm{C}$. The surface microstructure analysis showed the development in surface densification within the geopolymer when in contact with sintering temperature. It was found that the electrical conductivity was majorly influenced by the existence of the crystalline phase within the geopolymer sample. The highest electrical conductivity $\left(8.3 \times 10^{-4} \Omega \mathrm{m}^{-1}\right)$ was delivered by slag geopolymer due to the crystalline mineral of gehlenite $\left(3 \mathrm{Ca}_{2} \mathrm{Al}_{2} \mathrm{SiO}_{7}\right)$. Using synchrotron radiation $\mathrm{X}$-ray fluorescence, the high concentration Ca boundaries revealed the appearance of gehlenite crystallisation, which was believed to contribute to development of denser microstructure and electrical conductivity.
\end{abstract}

Keywords: geopolymer; microstructure analysis; phase analysis; electrical conductivity; sintering temperature

\section{Introduction}

Generally, Ordinary Portland Cement (OPC) allows sufficient thermal stability for most typical applications. However, at elevated temperatures, the properties of OPC fall off due to physical and chemical changes [1]. Several studies were conducted to identify an alternative material which possesses outstanding thermal stability and fire resistance in elevated temperature. Geopolymers are an amorphous three-dimensional (3D) aluminosilicate system, which was synthesised at ambient or slightly higher temperature by alkaline activation of suitable precursor raw material from industrial waste, fly ash [2-6], slag $[7,8]$, and kaolin $[9,10]$. It was shown that these inorganic materials that were identified, delivered an exceptional performance at elevated temperatures.

According to Davidovits [11], the geopolymer material delivered the ceramic behaviour with the existence of crystalline phases up to $1000{ }^{\circ} \mathrm{C}$. When heated or sintered at elevated temperatures, the transformation of the crystalline phase began to exist. Presently, Abdulkareem et al. [12] studied the fly ash geopolymer after having been heated up from ambient temperature to $800{ }^{\circ} \mathrm{C}$ without focussing on the changes in the phase composition, 
and element distribution occurred at elevated temperatures. Wang et al. [13] found that the structure of kaolin was majorly influenced by the calcination temperature. The change of aluminium species affected the structural changes of the geopolymer instead of the silicon atoms after having been heated at $900{ }^{\circ} \mathrm{C}$. Meanwhile, the crystallinity behaviour and microstructural change of the slag-based geopolymer at high-temperature conditions were investigated by Rovananik et al. [14]. The calcium aluminosilicate framework filled the pores between akermanite crystals after having been heated up to $1200^{\circ} \mathrm{C}$. The dense heated geopolymer displayed a glassy phase, which is the basis of ceramic. Traditionally, ceramic vitrification is commonly initiated from $900{ }^{\circ} \mathrm{C}$ on, which was marked by the melting of several solid phases that bound the present solid particles and led to enhancing the bonding strength $[15,16]$.

Meanwhile, according to Cui et al. [17], the electrical conductivity of geopolymer materials is intensively influenced by the microstructure appearance. The acceptable level of electrical conductivity is believed to play a major role in fast ionic conduction used for electrochemical sensors or solid-state batteries. Vladimirov et al. [18] reported that the overall electrical conductivity vitally depends on the density and nature of the grain boundaries. Understanding the microstructural and phase evolution at high sintering temperature towards electrical conductivity is strongly valuable for geopolymer and ceramic material.

Thus, the aims of this current work were to characterise the microstructural change, crystallographic evolution, and electrical conductivity at $900{ }^{\circ} \mathrm{C}$ sintering temperatures for kaolin, slag, and fly-ash-based geopolymers. Based on these results, the correlation between crystallography and electrical conductivity was clarified. The obtained observations were correlated with the element distribution obtained using the synchrotron source of micro-Xray fluorescence.

\section{Experimental Details}

Materials and Sample Preparation

The samples used in this were formed by precursor sources of kaolin (Associated Kaolin Industries Sdn Bhd, Perak, Malaysia), fly ash (Manjung Power Station, Perak, Malaysia), and slag (Ann Joo Integrated Steel Sdn Bhd, Penang, Malaysia) with the chemical composition as determined by the benchtop X-ray fluorescence spectrometer; PW4030 (Table 1). The sodium silicate $\left(\mathrm{Na}_{2} \mathrm{SiO}_{3}\right)$ solution used was provided by South Pacific Chemical Industries Sdn. Bhd., Malaysia, consisting of $\mathrm{SiO}_{2}(30.1 \%), \mathrm{Na}_{2} \mathrm{O}(9.4 \%)$, and $\mathrm{H}_{2} \mathrm{O}(60.5 \%)$ with $\mathrm{SiO}_{2} / \mathrm{Na}_{2} \mathrm{O}=3.2$. The $\mathrm{NaOH}$ clear solution was mixed with the sodium silicate solution and cooled down to ambient temperature one day before mixing.

Table 1. Chemical composition of kaolin, slag, and fly ash obtained by X-ray fluorescence.

\begin{tabular}{cccc}
\hline \multirow{2}{*}{ Element } & \multicolumn{3}{c}{ Mass (wt. \%) } \\
\cline { 2 - 4 } & Fly Ash & Kaolin & Slag \\
\hline $\mathrm{SiO}_{2}$ & 31.70 & 55.50 & 31.8 \\
$\mathrm{Al}_{2} \mathrm{O}_{3}$ & 14.30 & 31.20 & 10.5 \\
$\mathrm{CaO}$ & 23.40 & $\mathrm{~N} / \mathrm{A}$ & 50.37 \\
$\mathrm{Fe}_{2} \mathrm{O}_{3}$ & 23.92 & 4.40 & 0.53 \\
$\mathrm{~K}_{2} \mathrm{O}$ & 1.54 & 5.41 & $\mathrm{~N} / \mathrm{A}$ \\
$\mathrm{TiO}_{2}$ & 0.94 & 1.37 & 0.98 \\
$\mathrm{MgO}^{\mathrm{ZrO}}$ & 3.60 & $\mathrm{~N} / \mathrm{A}$ & 3.2 \\
$\mathrm{MnO}_{2}$ & $\mathrm{~N} / \mathrm{A}$ & 0.08 & 0.05 \\
$\mathrm{LOI}$ & $\mathrm{N} / \mathrm{A}$ & 0.11 & 0.71 \\
& 1.60 & 1.93 & 1.86 \\
\hline
\end{tabular}

The samples were designed based on three various mix geopolymer designs. Each raw aluminosilicate (kaolin, fly ash, and slag) powder, encompassing $\mathrm{NaOH}$ molarity, alkaline activator, solid-to-liquid ratio, and curing temperature were based on previous works 
and are tabulated in Table 2. The designated mixing design was based on the optimum mechanical performance [19-21]. The precursor material was mixed with the alkaline activator solution for $5 \mathrm{~min}$. The homogenised mixture was poured into a mould. Next, after curing for 28 days, the geopolymer was crushed and sieved at $38 \mu \mathrm{m}$ to produce a fine geopolymer powder. Two grams of each geopolymer powder were weighed and compressed via the powder metallurgy. Then, the samples were sintered at $900{ }^{\circ} \mathrm{C}$ (heating rate of $10{ }^{\circ} \mathrm{C} / \mathrm{min}$ and soaking time for $2 \mathrm{~h}$ ) by using a standard electrically heated furnace.

Table 2. Mixture proportion and classification of the geopolymer.

\begin{tabular}{cccc}
\hline \multirow{2}{*}{ Mix Design } & \multicolumn{2}{c}{ Material } & Slag \\
\cline { 2 - 4 } & Fly Ash & Kaolin & 10 \\
NaOH (M) & 12 & 8 & 2.5 \\
Alkaline activator ratio & 1.0 & 0.32 & 3.0 \\
Solid-to-liquid ratio & 2.5 & 1.0 & 25 \\
Curing temperature $\left({ }^{\circ} \mathrm{C}\right)$ & $\sim 25$ & 60 & SG \\
\hline Condition & & Classification & SG900 \\
\hline Unsintered & FG & KG900 &
\end{tabular}

\section{Characterisation and Analysis}

The microstructure surface analysis of the unsintered and sintered mixtures was performed using the JSM-6460LA model Scanning Electron Microscope (JEOL, Peabody, MA, USA) connected with secondary electron detectors. The samples were placed onto a double-sided carbon tape. The acceleration voltage and working distance were fixed at $10 \mathrm{kV}$ and $10 \mathrm{~mm}$, respectively.

The samples were examined from $400-4000 \mathrm{~cm}^{-1}$ (resolution of $4 \mathrm{~cm}^{-1}$ ) by using a Perkin Elmer FTIR Spectrum RX1 Spectrometer, Llantrisant, UK. The samples were prepared in powder form and then placed onto the sample slot (ATR crystal). Samples were evaluated by applying the potassium bromide $(\mathrm{KBr})$ pellets methodology. The shifting of the functional group of unsintered and sintered geopolymer was recorded.

The Brunauer-Emmet-Teller (BET) surface area and pore volume were measured by the nitrogen adsorption-desorption isotherm at $77 \mathrm{~K}$ volume (TrisStar 3000, Micrometrics Instrument Corporation, Norcross, GA, USA). The quantity adsorbed was correlated to the total surface area and pore volume of the particles in the samples.

The sample was fabricated in powder form for the phase analysis. The XRD analysis was performed by using an XRD-6000 Shimadzu X-ray diffractometer (Columbia City, IN, USA) $(\mathrm{Cu} \mathrm{K} \alpha$ radiation $(\lambda=1.5418 \AA)$ ). The analysis was operated at $40 \mathrm{kV}, 35 \mathrm{~mA}$ at $2 \theta$ ranging between $10^{\circ}$ to $80^{\circ}$ (scan rate of $1^{\circ} / \mathrm{min}$ ). The XRD pattern was analysed by using $X^{\prime}$ pert High score Plus 2.0 Software by Malvern Panalytical Ltd. (Malvern, UK).

The samples were measured at ambient temperature by using four-point probe that was set up by Keithly, which was selected due to the measurement ability without contact resistance interference. The probe spacing (s) of $1 \mathrm{~mm}$ was used, and a current subjected to the samples was set at $0.15 \mathrm{~s} / \mathrm{cm}$ and $1 \mathrm{~A}$. The following equations were used to calculate the electrical conductivity of the samples.

$$
\begin{gathered}
\rho=2 \pi \mathrm{s}\left(\frac{V}{I}\right) \\
\sigma=\frac{1}{\rho}
\end{gathered}
$$

where;

$\rho=$ resistivity,

$\mathrm{s}=$ probe space, 
$V=$ voltage,

$I=$ current, and

$\sigma=$ conductivity.

The element distributions in the sintered geopolymer were performed by using a synchrotron $\mu$-XRF at BL6b beamline at the Synchrotron Light Research Institute (SLRI) located in Bangkok, Thailand. The detection limits at the sub-parts per million concentration level could be obtained for larger than $100 \mathrm{~nm}$, and the sensitivities approached the attogram (10-18 g) level [22]. The polycapillary lens was used to initiate a micro-X-ray beam (size of $30 \mu \mathrm{m} \times 30 \mu \mathrm{m}$ ) on the samples and focussed the continuous synchrotron radiation. The range energy micro-X-ray beam was set (2 to $12 \mathrm{keV}$ ) without the monochromator feature. The experiments were conducted in a helium gas atmosphere with $30 \mathrm{~s}$ of exposure time at each point. The resulting images were created in bilinear interpolation and analysed using PyMca software [23]. Figure 1 depicts the sample specification and the localised scan point on the surface of the samples.

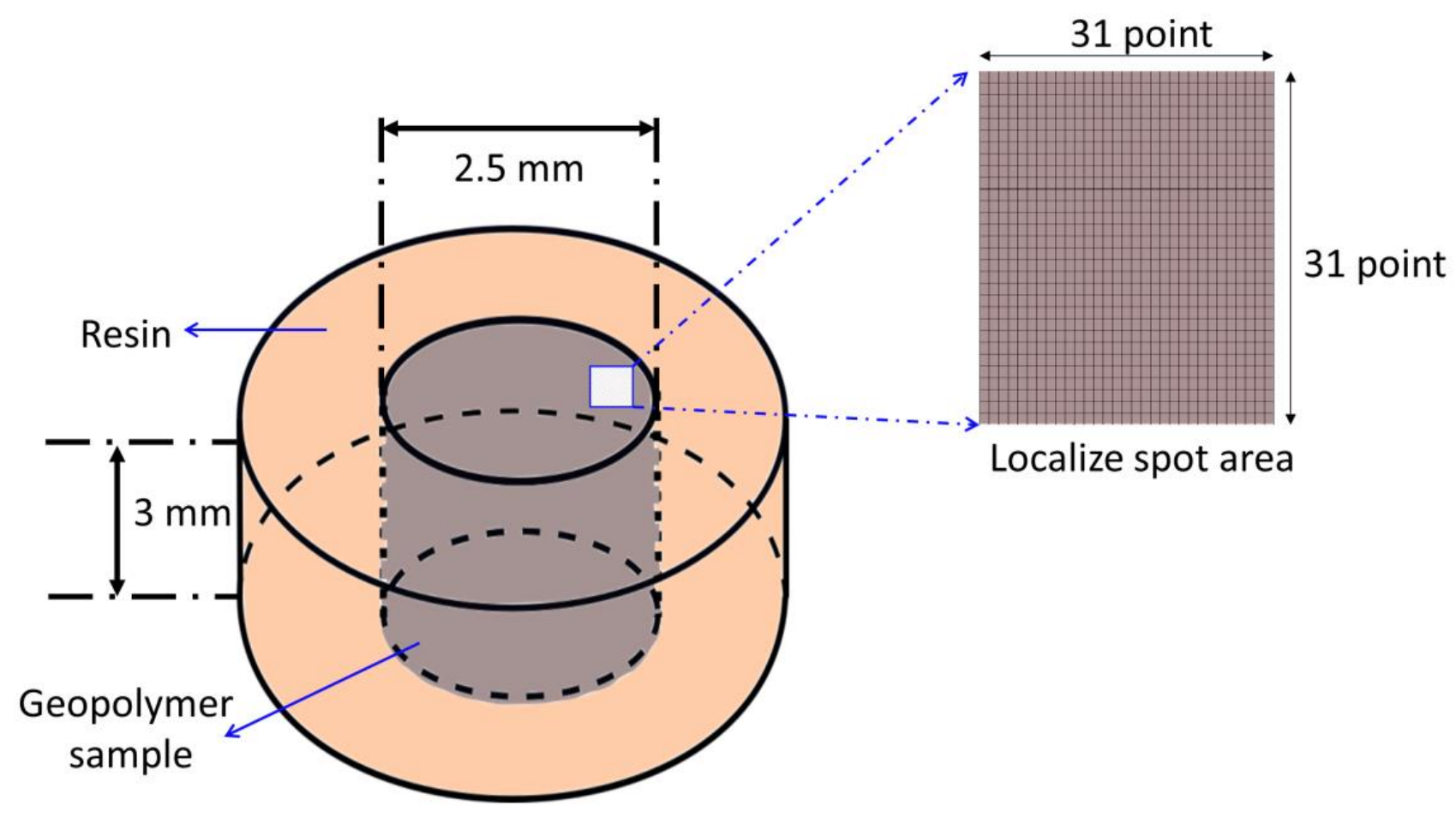

Figure 1. Specification of the sample for the synchrotron micro-X-ray fluorescence.

\section{Result and Discussion}

\subsection{Microstructure Analysis}

The microstructure of the fly ash, kaolin, slag geopolymers subjected to the sintering temperatures as investigated by SEM are shown in Figure 2. The unsintered fly ash geopolymer (Figure 2a) showed that there was an incomplete dissolution of the fly ash spheres, while the presence of well-defined clay platelets in the kaolin geopolymer was shown in Figure 2b. The small amount of remnant slag particles within the rough surface can be seen in Figure 2c. The remnant slag particles were enclosed within the geopolymer matrix [19]. The micrographs of the unsintered geopolymer revealed that the higher curing temperature is adequate for the development of a structurally firm geopolymer. 

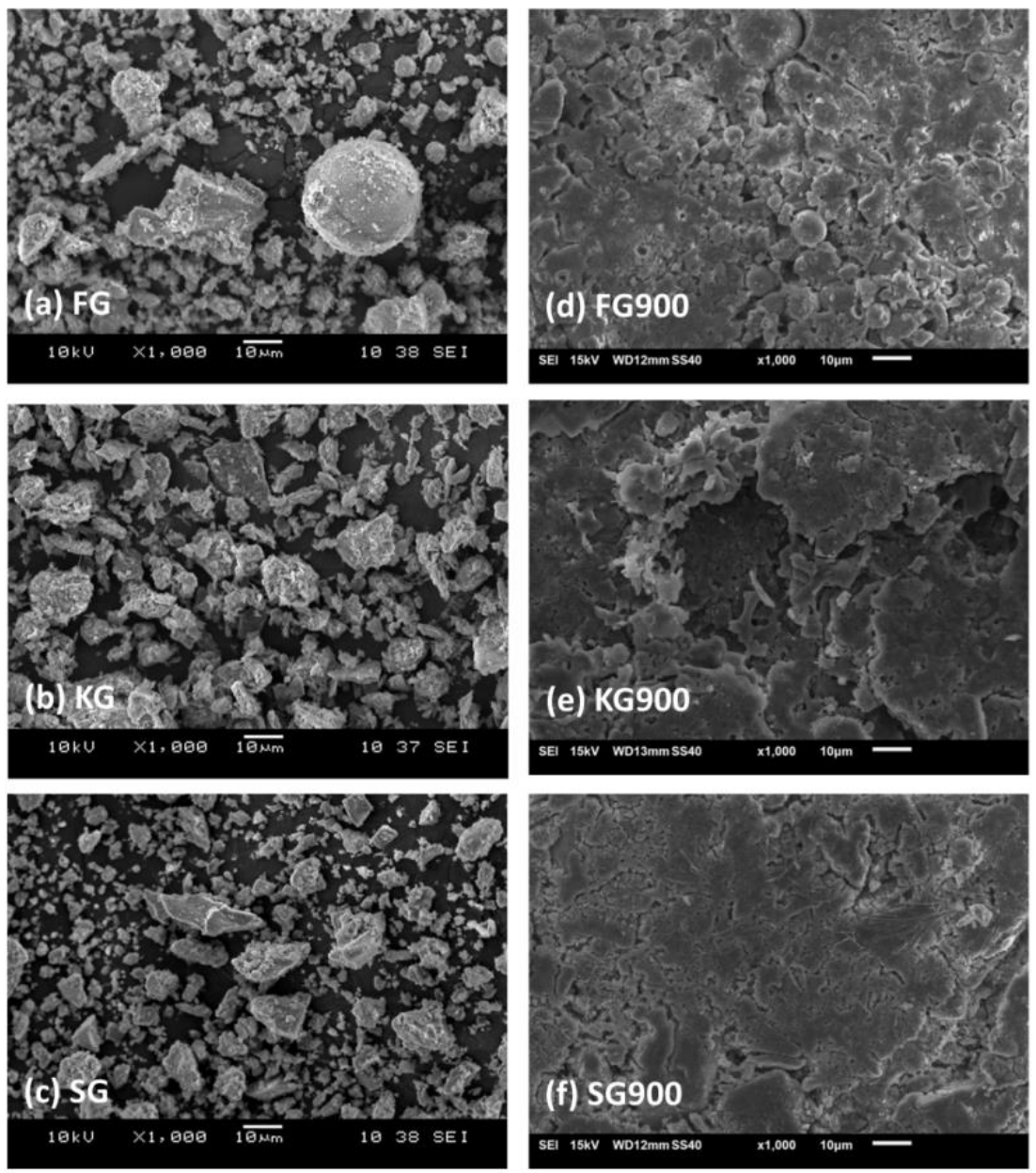

Figure 2. SEM micrograph of the unsintered (a) Fly ash geopolymer (b) Kaolin geopolymer (c) Slag geopolymer and sintered geopolymer at $900{ }^{\circ} \mathrm{C}$ (d) Sintered Fly ash geopolymer (e) Sintered Kaolin geopolymer (f) Sintered Slag geopolymer.

After sintered at $900{ }^{\circ} \mathrm{C}$, a smooth and denser geopolymer surface could be clearly seen in the matrix, as shown in Figure 2d-f. By referring to Figure 2d, the existence of micro cracks with lesser remnant fly ash particles was observed, as indicated by the sphericalshaped particles. The kaolin geopolymer surface became increasingly glassy and smooth with the sintering temperature at $900{ }^{\circ} \mathrm{C}$ (Figure 2e). The change in the microstructure was supposedly due to the hydration of moisture and phase transformation that was discussed in the next section. Simultaneously, at the same sintering temperature of $900{ }^{\circ} \mathrm{C}$, the slag geopolymer surface revealed lesser cracks and pore formations. The crack healing ability of the slag geopolymer caused the reduction of crack lines in conjunction with the partial melting. This result was supported by the findings of Dudek et al. [24].

\subsection{Pore Structure Analysis}

The influence of the sintering temperature $\left(900^{\circ} \mathrm{C}\right)$ on the pore structure of geopolymer samples was analysed by Brunauer-Emmett-Teller (BET) technology. The specific surface area and pore volume of the unsintered and sintered geopolymer are depicted in Figure 3. The Kaolin geopolymer (KG) sample obtained the lowest surface area $\left(0.86 \mathrm{~m}^{2} / \mathrm{g}\right)$ and pore volumes $\left(0.03 \mathrm{~cm}^{3} / \mathrm{g}\right)$, while the Fly ash geopolymer (FG) sample delivered the highest surface area $\left(26.6 \mathrm{~m}^{2} / \mathrm{g}\right)$ and pore volume $\left(0.07 \mathrm{~cm}^{3} / \mathrm{g}\right)$. Fly ash was the by-product of coal combustion in a thermal power plant [25], always accommodating unburned carbon, which led to a porous material that delivered a higher surface area, as shown in Figure 3. 

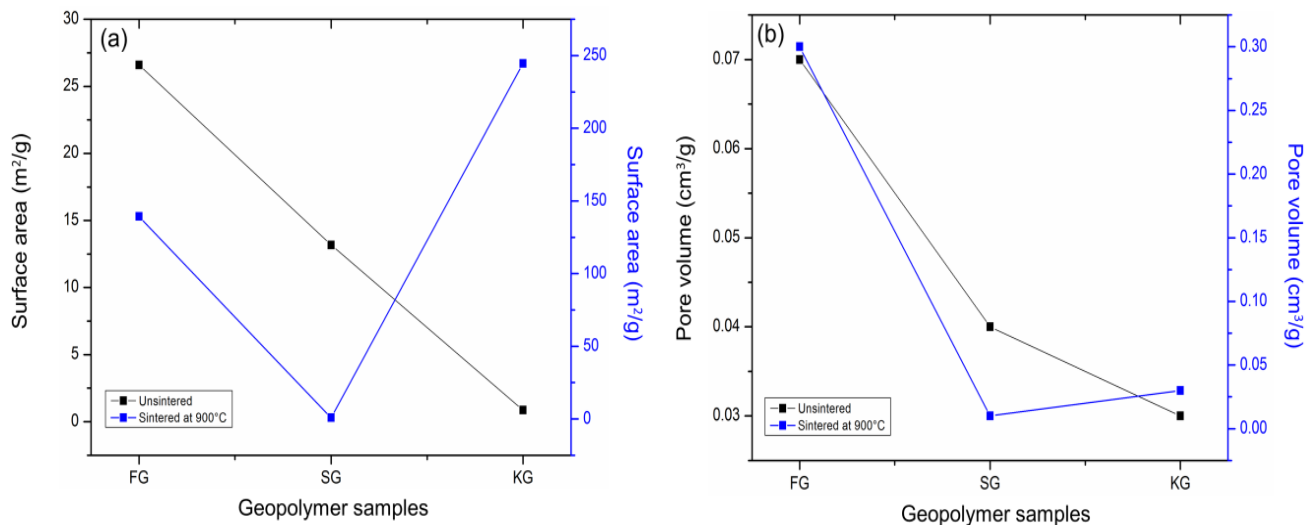

Figure 3. Pore structure of the geopolymer samples towards $900{ }^{\circ} \mathrm{C}$ sintering temperature; (a) surface area and (b) pore volume.

It can be seen in Figure 3 after having been sintered at $900{ }^{\circ} \mathrm{C}$, Slag geopolymer (SG) showed the lowest value of surface area $\left(0.86 \mathrm{~m}^{2} / \mathrm{g}\right)$ and pore volume $\left(0.01 \mathrm{~cm}^{3} / \mathrm{g}\right)$ compared to KG900 and FG900. The small surface area and pore volume indicated that the SG900 is compacted and denser, thus, contributed to lower permeability due to the minimisation of porosity. This was also supported by the microstructure analysis, as shown in Figure 2c. The slag particle was believed to be consisting of mesopores-type in minor quantity, thus, obtained lower surface areas after having been introduced to the high sintering temperature.

\subsection{Structural Spectra Analysis}

The Fourier-transform infrared spectroscopy (FTIR) of the unsintered and sintered geopolymer at $900{ }^{\circ} \mathrm{C}$ is shown in Figure 4 . The unsintered geopolymer presented a broad absorption band at $\sim 1000 \mathrm{~cm}^{-1}$ and $\sim 500 \mathrm{~cm}^{-1}$, corresponding to the huge fingerprints of the geopolymer structure, which identified as stretching vibrations of $\mathrm{Si}-\mathrm{O}-\mathrm{Si} / \mathrm{Al}$ aluminosilicates, as depicted in Figure 4a. The weak $\mathrm{OH}^{-}$stretching vibration and bending modes were determined at $\sim 3600 \mathrm{~cm}^{-1}$ and $\sim 1650 \mathrm{~cm}^{-1}$, respectively. These OH vibrations were found majorly because of the typical water bond absorption in the geopolymer product. Meanwhile, the narrow peaks, obtained at $1430-1500 \mathrm{~cm}^{-1}$, corresponded to the existence of the carbonate compound $(\mathrm{CO})_{3}{ }^{2-}$. The slag geopolymer delivered the highest wavenumber at $\sim 1500 \mathrm{~cm}^{-1}$, as it contained a higher level of $\mathrm{CaO}$ in the material, which indicated the vibration of calcite [26].
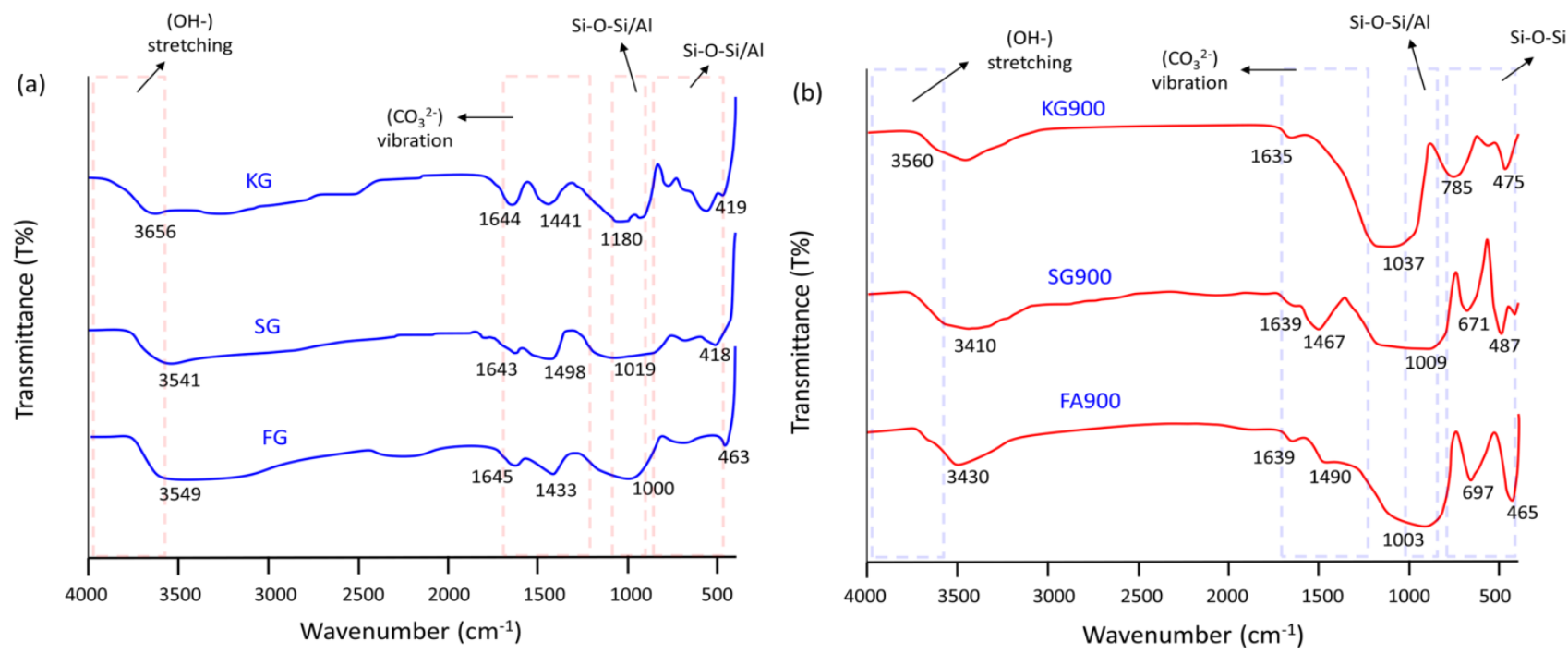

Figure 4. Fourier-transform infrared spectroscopy (FTIR) of the (a) unsintered and (b) sintered geopolymer at $900{ }^{\circ} \mathrm{C}$. 
Figure $4 \mathrm{~b}$ clearly portrays that there was a remarkable change in the absorption bands after having been sintered at $900{ }^{\circ} \mathrm{C}$, indicating the full dehydration of geopolymer. It was evident that in the considerable broadening of the spectral region of $1000-1037 \mathrm{~cm}^{-1}$ in the samples sintered at $900{ }^{\circ} \mathrm{C}$. The band shifted to a lower wavenumber; kaolin geopolymer $\left(1037 \mathrm{~cm}^{-1}\right)$, slag geopolymer $\left(1009 \mathrm{~cm}^{-1}\right)$, and fly ash geopolymer $\left(1000 \mathrm{~cm}^{-1}\right)$ due to the vibrations of $\mathrm{Si}-\mathrm{O}-\mathrm{Al}$ asymmetric telescopic and $\mathrm{Si}-\mathrm{O}-$-symmetrical stretching tetrahedrally as a result of the geopolymer edifice. The existence of new bands at $700-780 \mathrm{~cm}^{-1}$ was attributable to the symmetrical stretching vibration of the $\mathrm{Si}-\mathrm{O}-\mathrm{Si}(\mathrm{Al})$ bridges corresponding to crystalline minerals such as quartz, gehlenite, and akermanite $[9,27]$. The appearance of these crystalline phases was further confirmed in the next phase analysis section. A typical observation was revealed for various geopolymers sintered to elevated temperatures, whereby the weak-vibration mode at $3400-3500 \mathrm{~cm}^{-1}$ and $\sim 1640 \mathrm{~cm}^{-1}$ lowered the intensity at $900{ }^{\circ} \mathrm{C}$, which was attributed to the $\mathrm{OH}$ stretching and bending vibration, suggesting the full dehydration of the geopolymer.

\subsection{Phase Transformation}

Figure $5 \mathrm{a}, \mathrm{b}$ presents the XRD diffractograms of the unsintered and sintered geopolymers. Unsintered fly ash and slag geopolymers showed broad humps of the amorphous phase $2 \theta, 15-35^{\circ}$ with several crystalline phases of quartz ( $Q$, PDF No $=01-078-1258$ and 01-071-0911) and calcite (C, PDF No = 00-051-1524 and 01-085-1108). The appearance of broad humps also corresponded with the formation of the geopolymer phase. Meanwhile, unsintered kaolin had a semi-crystalline phase diffusing halo at 20-38 $2 \theta$, mainly of kaolinite (K, PDF No = 00-029-1428). The trace quantity of quartz (, , PDF No $=01-089-8937)$ could be found in KG. The elevated temperature enhanced the propensity towards the formation of a stable crystalline phase for fly ash and slag geopolymer, portrayed in Figure 5b.

(a)

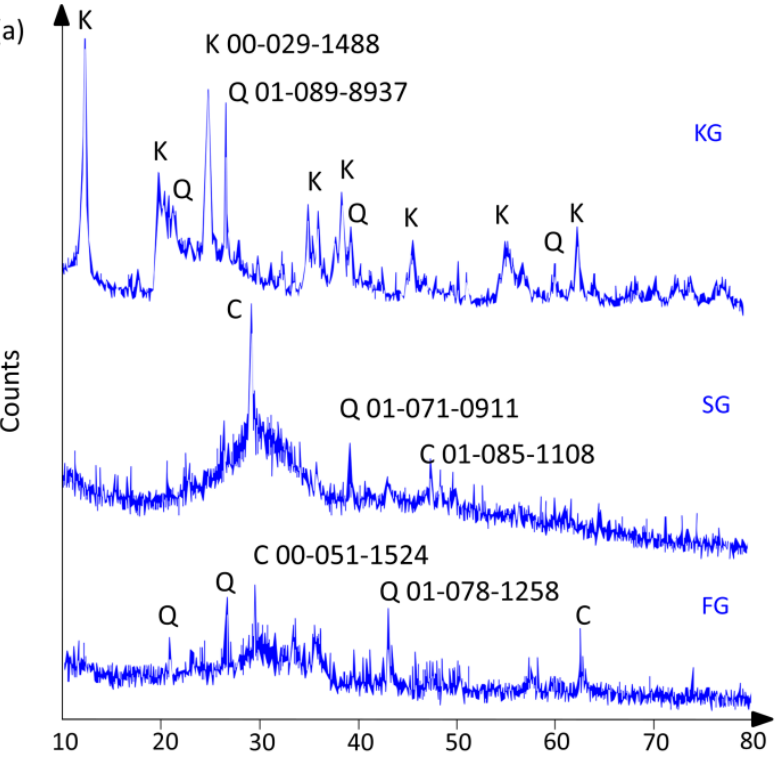

(b)

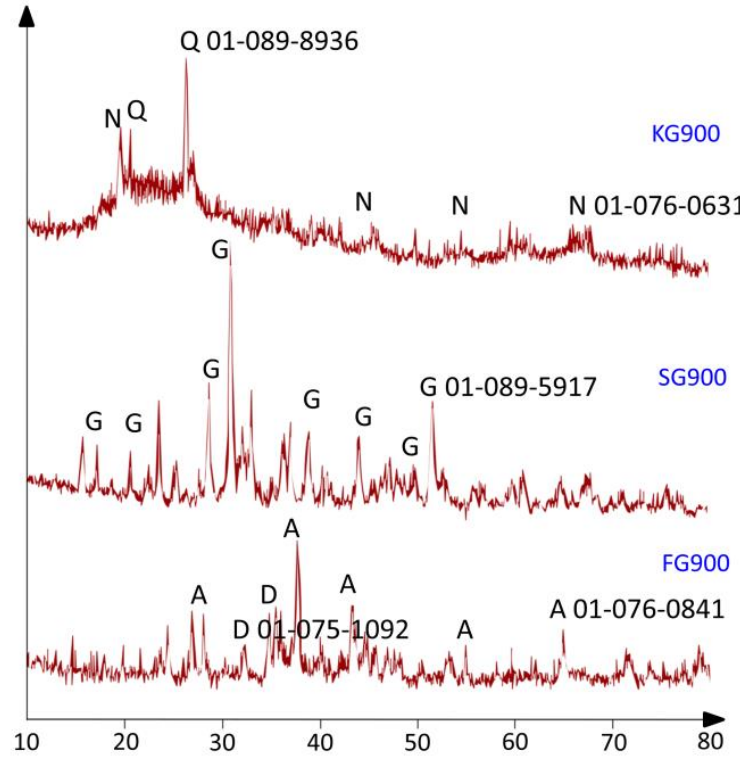

Figure 5. XRD diffractogram of (a) the unsintered geopolymer; K-kaolin (PDF No. 00-029-1488), Q-quartz (PDF No. 01-089-8937, 01-071-0911 and 01-078-1258), C-calcite (PDF No. 00-051-1524) and (b) the sintered geopolymer, Q- quartz (PDF No. 01-089-08936), N-nepheline (PDF No. 01-076-0631), G—gehlenite (PDF No. 01-089-5917), A—akermanite (PDF No. 01-076-0841), D-diopside (PDF No. 01-075-1092).

The formation of gehlenite, akermanite, and diopside could be seen in the samples sintered at $900^{\circ} \mathrm{C}$. Commonly, the evolution of the crystalline phase might act as fillers to reinforce the matrix and enhance thermal stability. The crystallisation also enhanced the denser microstructure, as exhibited in the SEM images shown in Figure 2. Based on Heah et al. [28], the crystallisation at the elevated temperature developed the mechanical properties of the geopolymer, which was believed contributed by the denser surface. 
The de-carbonation at $900{ }^{\circ} \mathrm{C}$ contributed to the decomposition of calcium hydrates and the reduction intensity of calcite. Silica, calcium oxide, and aluminium oxide were liberated from the geopolymer matrix to produce the crystalline phase of gehlenite, as shown in Equation (3) [29].

$$
3 \mathrm{SiO}_{2} \cdot \mathrm{Al}_{2} \mathrm{O}_{3}+6 \mathrm{CaO} \rightarrow 3 \mathrm{Ca}_{2} \mathrm{Al}_{2} \mathrm{SiO}_{7} \text { (gehlenite) }
$$

Meanwhile, akermanite was produced, as a major crystalline mineral, as a result of the reaction between calcite and free magnesium and silica oxide according to Equation (4) [30].

$$
2 \mathrm{CaCO}_{3}+\mathrm{MgO}+2 \mathrm{SiO}_{2} \rightarrow \mathrm{Ca}_{2} \mathrm{MgSi}_{2} \mathrm{O}_{7} \text { (akermanite) }+\mathrm{CO}_{2}
$$

The contradict phase analysis was obtained by KG900. Upon sintered at $900{ }^{\circ} \mathrm{C}$, the portion of kaolinite phases transformed into semi-crystalline nepheline diffraction peaks. Based on previous studies, nepheline crystals were formed in heated-treated sodium-based geopolymers [31]. According to Sabbatini et al. [32], the existence of nepheline assisted the improvement of mechanical performance as the result of the favourable amount of silicon-rich and polymerised species. This was also corroborated with the chemical analysis of FTIR peaks, as sintered-kaolin geopolymer showed higher vibrations of $\mathrm{Si}-\mathrm{O}-\mathrm{Si} / \mathrm{Al}$ aluminosilicates at $\sim 1000 \mathrm{~cm}^{-1}$ (Figure 4 ).

\subsection{Electrical Conductivity}

The electrical conductivity was measured based on the concern of the geopolymeric matrix as potential reinforcement material in the electronic application. The result of Figure 6 shows the electrical conductivity value of the unsintered and sintered geopolymers. The highest conductivity values were depicted by SG $\left(5.62 \times 10^{-4} \Omega \mathrm{m}^{-1}\right)$, while the lowest values were obtained by FG $\left(5.19 \times 10^{-4} \Omega \mathrm{m}^{-1}\right)$ for the unsintered samples. The electrical conductivity in SG could be explained as a result of ion mobility $\left(\mathrm{Ca}^{2+}, \mathrm{OH}^{-}, \mathrm{Na}^{+}\right)$and electron transport across the percolated network of the calcium-based geopolymer. These existing ions were freely absorbed by a thin layer of the hydration product, such as calcium carbonate $\left(\mathrm{CaCO}_{3}\right)$, as shown in Figure 4. Meanwhile, iron-rich particles in fly ash were found as the major cause for the lower electrical conductivity. The metallic iron particle was believed to exclude from the fly ash geopolymerisation. The unreacted spherical particles clearly could be visualised in Figure 2. This was also in accordance with the results published by Alida et al. [21].

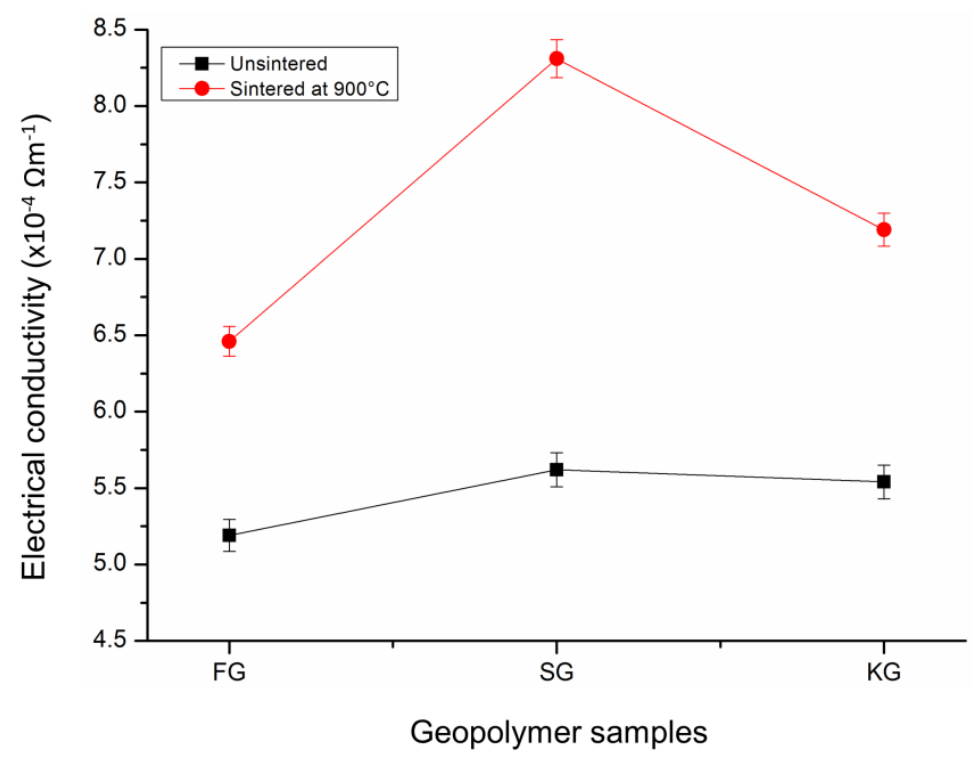

Figure 6. Electrical conductivity of the unsintered and sintered geopolymers at $900{ }^{\circ} \mathrm{C}$. 
On being sintered to $900{ }^{\circ} \mathrm{C}$ temperatures, the electrical conductivity of the geopolymers was found to increase. As it could be observed in Figure 6, SG900 exhibited a higher electrical conductivity than FG900 and KF900. For example, the electrical conductivity of SG900 was increased by $47.9 \%$, compared to the FG900 (24.5\%) and KG900 (29.8\%) sintered geopolymer, respectively. The significant increase in electrical conductivity was attributed to the denser microstructure and lesser pores appearance, which connected the paths of the electron transportation and enhanced the electrical conductivity.

As can be observed in Figure 7, the microstructure displayed the crystalline grains structure after the geopolymer sintered at $900{ }^{\circ} \mathrm{C}$. The development of the ordered structure indicated the occurrence of necking grain growth, resulting in material densification [33,34]. The necking grain facilitated the additional conductive pathway on the crystalline microstructure. The structure rearrangement into the crystalline phase enhanced the alkali metal-ion transfer rate and electrical conductivity [35].
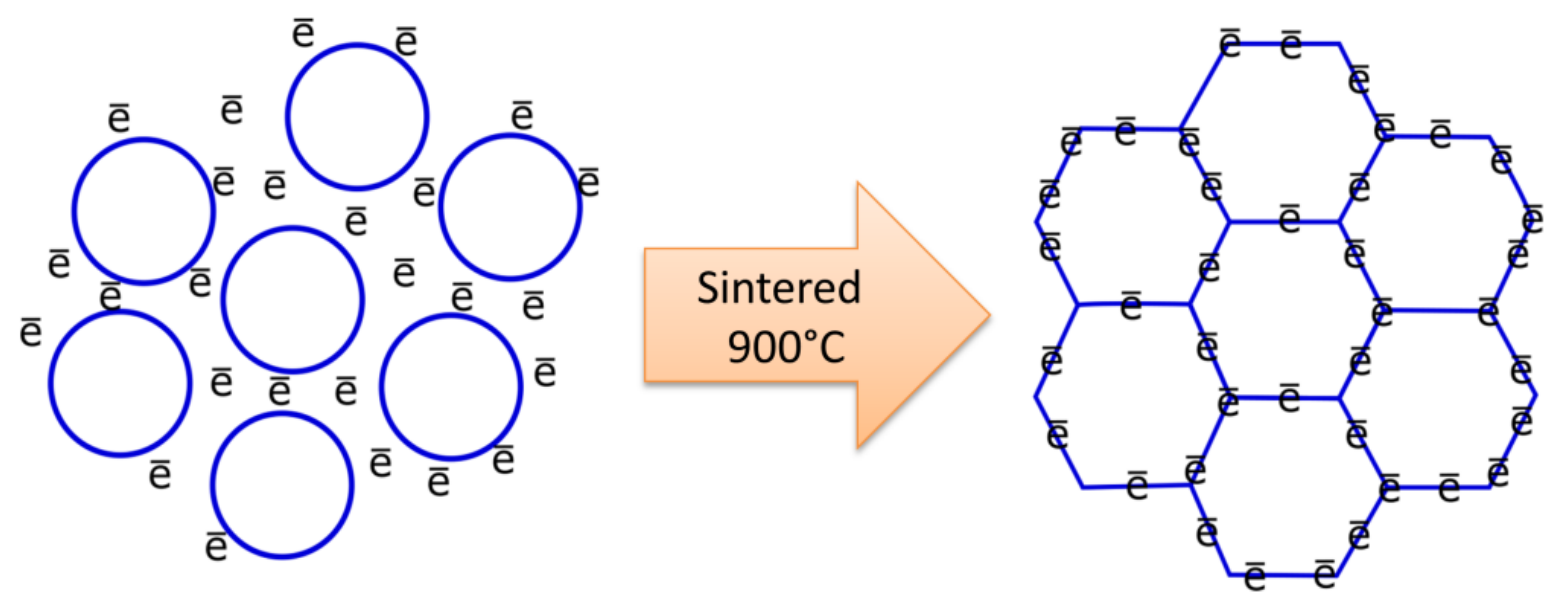

Figure 7. Proposed electron pathway at the crystalline grains structure at $900{ }^{\circ} \mathrm{C}$ sintering temperature.

\subsection{Elemental Distribution Analysis}

The sintered geopolymer was analysed, by using the synchrotron micro-XRF analysis, in order to determine the element distribution and potential existence crystalline phase at $900{ }^{\circ} \mathrm{C}$. Figure 8 depicts the particular area and the micro-XRF images in $\mathrm{Si}-\mathrm{Al}-\mathrm{Ca}$ of the sintered geopolymer, signifying these elements were well distributed within the samples. By using this advanced technique, the distribution of the major elements (calcium), including light elements (silicon and alumina), could be easily traced.

By referring to Figure 8 , the distribution of $\mathrm{Si}$ and $\mathrm{Al}$ was classified for the identification of the geopolymer main chain $(\mathrm{Si}-\mathrm{O}-\mathrm{Al} / \mathrm{Si})$. In general, the colours blue, green, and red represented low, medium, and high intensities for each distribution element at the integrated area. For KG900, the high concentrated Si region (red colour) reflected the quartz grain, while the medium concentration (green colour) of the Si element was indicated in the good homogeneity of the samples. Meanwhile, the Ca distribution was portrayed in the region of hydrated minerals of the FG900 and SG900 sintered geopolymers. The high concentrated $\mathrm{Ca}$ territory corresponded to the existence of gehlenite $\left(3 \mathrm{Ca}_{2} \mathrm{Al}_{2} \mathrm{SiO}_{7}\right)$ and akermanite $\left(\mathrm{Ca}_{2} \mathrm{MgSi}_{2} \mathrm{O}_{7}\right)$. Regions with a lower concentration of $\mathrm{Ca}$ distribution reflected the boundaries of diopside $\left(\mathrm{MgCaSi}_{2} \mathrm{O}_{6}\right)$, which formed a minor crystal within the crystalline geopolymer, as corroborated in Figure 5. These Ca-rich crystalline minerals were confirmed to be contributing to a denser microstructure appearance, as portrayed in Figure 2. The elevated temperature resulted in significant changes in the microstructure evolution, edging it towards the formation of a stable crystalline phase. 


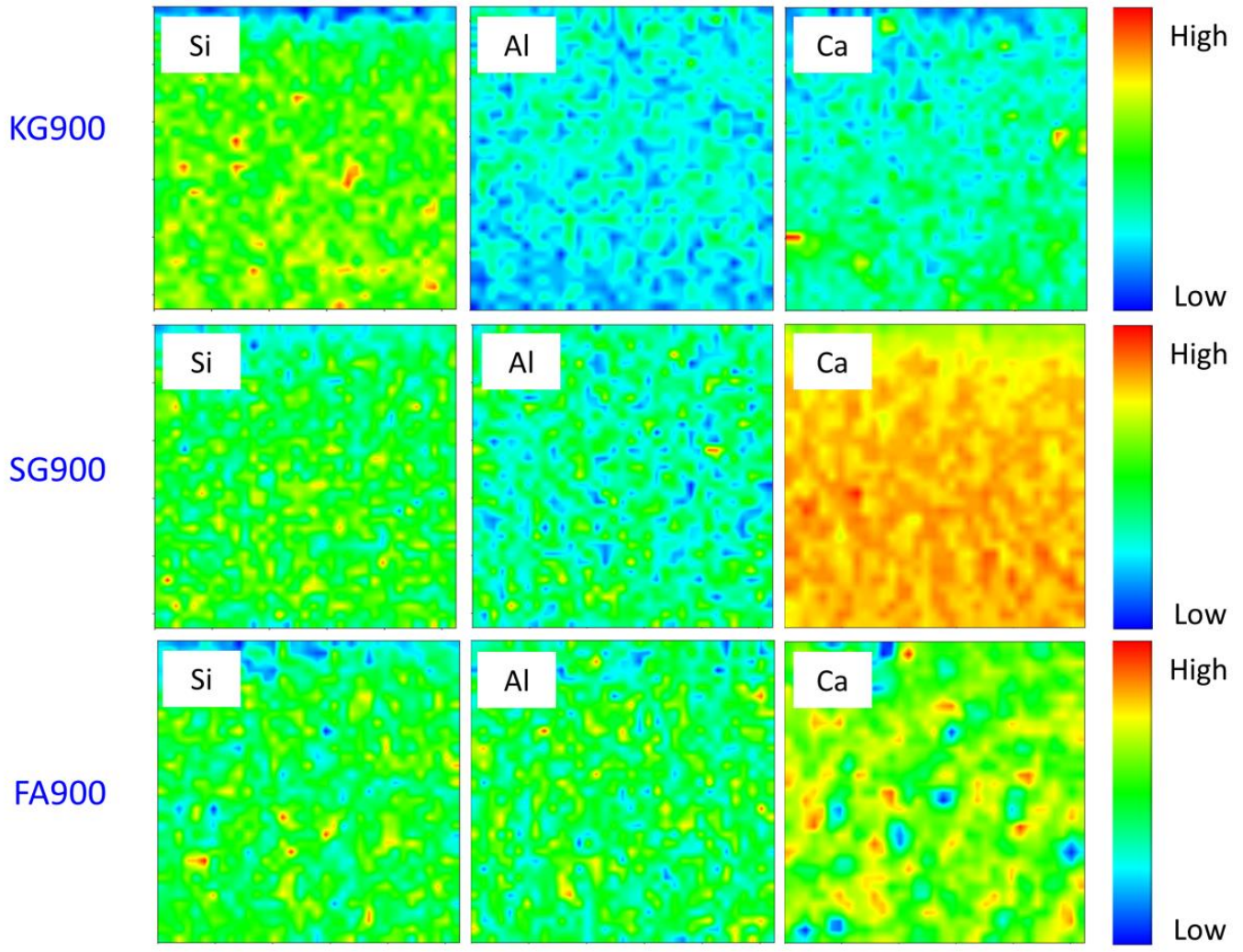

Figure 8. Micro-XRF elemental distribution maps of $\mathrm{Si}-\mathrm{Al}-\mathrm{Ca}$ in the sintered geopolymers at $900{ }^{\circ} \mathrm{C}$.

\section{Conclusions}

The microstructure evolution, phase transformation, and electrical conductivity of kaolin, fly ash, and slag geopolymers at sintering temperature were analysed experimentally in this paper. The influence of sintering temperatures towards crystallisation, chemical bonding analysis, and element distribution of geopolymers were investigated. The microstructure analysis obtained the development of surface densification and lesser pores within the geopolymer matrix. The X-ray diffraction revealed that the crystallisation of gehlenite, akermanite, and nepheline was determined at $900{ }^{\circ} \mathrm{C}$. The electrical conductivity measurement showed that the crystalline geopolymer could be proposed as a potential reinforcement material in electronic applications, especially in solder composites.

Author Contributions: Conceptualization, N.N.I.Z., M.M.A.B.A., M.A.A.M.S. and I.H.A.; methodology, N.N.I.Z., M.M.A.B.A., M.A.A.M.S. and I.H.A.; software, M.A.A.M.S., M.M.A.B.A., I.H.A. and J.C.; validation, M.M.A.B.A., M.A.A.M.S. and I.H.A.; formal analysis, M.M.A.B.A., M.A.A.M.S. and I.H.A.; investigation, N.N.I.Z., M.M.A.B.A., and M.A.A.M.S.; resources, M.M.A.B.A., M.A.A.M.S. and J.C.; data curation, N.N.I.Z., M.M.A.B.A., M.A.A.M.S. and I.H.A.; writing-original draft preparation, N.N.I.Z., M.M.A.B.A., M.A.A.M.S. and I.H.A.; writing-review and editing, M.M.A.B.A., M.A.A.M.S. and I.H.A.; visualization, M.M.A.B.A., M.A.A.M.S., D.K., M.G. (Marcin Gacek) and M.G. (Marek Gucwa); supervision, M.M.A.B.A. and M.A.A.M.S.; project administration, M.M.A.B.A. and M.A.A.M.S.; funding acquisition, M.M.A.B.A., M.A.A.M.S., D.K., M.G. (Marcin Gacek) and M.G. (Marek Gucwa). All authors have read and agreed to the published version of the manuscript.

Funding: This work was supported by Ministry of Higher Education, Malaysia and Newton fund under ISIS Neutron and Muon Source, Ministry of Education Malaysia (MOE), under reference no: JPT.S (BPKI)2000/016/018/019(29). Neutron tomography studies of geopolymer ceramic used for reinforcement materials in solder alloy for a robust electric/electronic solder joint under reference no: JPT.S (BPKI)2000/016/018/019(29).

Institutional Review Board Statement: Not applicable.

Informed Consent Statement: Not applicable. 
Data Availability Statement: The data presented in this study are available on request from the corresponding author.

Acknowledgments: The authors gratefully acknowledged the Ministry of Higher Education, Malaysia and Newton fund under ISIS Neutron and Muon Source, Ministry of Education Malaysia (MOE), under reference no: JPT.S (BKPI)2000/016/018/019(29) for the financial support. The authors would like to acknowledge Geopolymer \& Green Technology, Centre of Excellence (CEGeoGTech), University Malaysia Perlis (UniMAP), Faculty of Chemical Engineering Technology, UniMAP for the support. The author would also like to acknowledge the support from Nihon Superior. The authors would like to extend their gratitude to the Department of Physics and the Faculty of Mechanical Engineering and Computer Science, Częstochowa University of Technology, Częstochowa, Poland.

Conflicts of Interest: The authors declare no conflict of interest.

\section{References}

1. Kong, D.L.; Sanjayan, J.G. Effect of elevated temperatures on geopolymer paste, mortar and concrete. Cem. Concr. Res. 2010, 40, 334-339. [CrossRef]

2. Taye, E.; Roether, J.; Schubert, D.; Redda, D.; Boccaccini, A. Hemp Fiber Reinforced Red Mud/Fly Ash Geopolymer Composite Materials: Effect of Fiber Content on Mechanical Strength. Materials 2021, 14, 511. [CrossRef]

3. Shahedan, N.; Abdullah, M.; Mahmed, N.; Kusbiantoro, A.; Tammas-Williams, S.; Li, L.-Y.; Aziz, I.; Vizureanu, P.; Wysłocki, J.; Błoch, K.; et al. Properties of a New Insulation Material Glass Bubble in Geo-Polymer Concrete. Materials 2021, 14, 809. [CrossRef]

4. Zailani, W.W.A.; Abdullah, M.M.A.B.; Arshad, M.F.; Razak, R.A.; Tahir, M.F.M.; Zainol, R.R.M.A.; Nabialek, M.; Sandu, A.V.; Wysłocki, J.J.; Błoch, K. Characterisation at the Bonding Zone between Fly Ash Based Geopolymer Repair Materials (GRM) and Ordinary Portland Cement Concrete (OPCC). Materials 2020, 14, 56. [CrossRef]

5. Faris, M.; Abdullah, M.; Muniandy, R.; Abu Hashim, M.; Błoch, K.; Jeż, B.; Garus, S.; Palutkiewicz, P.; Mortar, N.M.; Ghazali, M. Comparison of Hook and Straight Steel Fibers Addition on Malaysian Fly Ash-Based Geopolymer Concrete on the Slump, Density, Water Absorption and Mechanical Properties. Materials 2021, 14, 1310. [CrossRef]

6. Li, O.H.; Yun-Ming, L.; Cheng-Yong, H.; Bayuaji, R.; Abdullah, M.M.A.B.; Loong, F.K.; Jin, T.S.; Teng, N.H.; Nabiałek, M.; Jeż, B.; et al. Evaluation of the Effect of Silica Fume on Amorphous Fly Ash Geopolymers Exposed to Elevated Temperature. Magnetochemistry 2021, 7, 9. [CrossRef]

7. Lancellotti, I.; Piccolo, F.; Traven, K.; Češnovar, M.; Ducman, V.; Leonelli, C. Alkali Activation of Metallurgical Slags: Reactivity, Chemical Behavior, and Environmental Assessment. Materials 2021, 14, 639. [CrossRef] [PubMed]

8. Jamil, N.; Abdullah, M.; Pa, F.C.; Hasmaliza, M.; Ibrahim, W.W.; Aziz, I.A.; Jeż, B.; Nabiałek, M. Phase Transformation of Kaolin-Ground Granulated Blast Furnace Slag from Geopolymerization to Sintering Process. Magnetochemistry $2021,7,32$. [CrossRef]

9. Elimbi, A.; Tchakoute, H.; Njopwouo, D. Effects of calcination temperature of kaolinite clays on the properties of geopolymer cements. Constr. Build. Mater. 2011, 25, 2805-2812. [CrossRef]

10. Ariffin, N.; Abdullah, M.; Postawa, P.; AbdRahim, S.Z.; Zainol, M.R.R.M.A.; Jaya, R.; Śliwa, A.; Omar, M.; Wysłocki, J.; Błoch, K.; et al. Effect of Aluminium Powder on Kaolin-Based Geopolymer Characteristic and Removal of Cu ${ }^{2+}$. Materials 2021, 14, 814. [CrossRef]

11. Davidovits, J. Geopolymer Cement. A Review; Technical Paper 21; Geopolymer Institute: Saint-Quentin, France, 2013 ; pp. 1-11.

12. Abdulkareem, O.A.; Al Bakri, A.M.; Kamarudin, H.; Nizar, I.K.; Saif, A.A. Effects of elevated temperatures on the thermal behavior and mechanical performance of fly ash geopolymer paste, mortar and lightweight concrete. Constr. Build. Mater. 2014, 50, 377-387. [CrossRef]

13. Wang, M.; Jia, D.; He, P.; Zhou, Y. Influence of calcination temperature of kaolin on the structure and properties of final geopolymer. Mater. Lett. 2010, 64, 2551-2554. [CrossRef]

14. Rovnaník, P.; Bayer, P.; Rovnaníková, P. Characterization of alkali activated slag paste after exposure to high temperatures. Constr. Build. Mater. 2013, 47, 1479-1487. [CrossRef]

15. Lemougna, P.N.; Yliniemi, J.; Ismailov, A.; Levanen, E.; Tanskanen, P.; Kinnunen, P.; Roning, J.; Illikainen, M. Recycling lithium mine tailings in the production of low temperature $\left(700-900{ }^{\circ} \mathrm{C}\right)$ ceramics: Effect of ladle slag and sodium compounds on the processing and final properties. Constr. Build. Mater. 2019, 221, 332-344. [CrossRef]

16. Aziz, I.H.; Abdullah, M.M.A.B.; Yong, H.C.; Ming, L.Y.; Hussin, K.; Surleva, A.; Azimi, E.A. Manufacturing parameters influencing fire resistance of geopolymers: A review. Proc. Inst. Mech. Eng. Part L J. Mater. Des. Appl. 2016, 233, 721-733. [CrossRef]

17. Cui, X.-M.; Zheng, G.-J.; Han, Y.-C.; Su, F.; Zhou, J. A study on electrical conductivity of chemosynthetic $\mathrm{Al}_{2} \mathrm{O}_{3}-2 \mathrm{SiO}_{2}$ geoploymer materials. J. Power Sources 2008, 184, 652-656. [CrossRef]

18. Vladimirov, I.; Kühn, M.; Geßner, T.; May, F.; Weitz, R.T. Energy barriers at grain boundaries dominate charge carrier transport in an electron-conductive organic semiconductor. Sci. Rep. 2018, 8, 1-10. [CrossRef]

19. Aziz, I.H.; Abdullah, M.M.A.B.; Heah, C.-Y.; Liew, Y.-M. Behaviour changes of ground granulated blast furnace slag geopolymers at high temperature. Adv. Cem. Res. 2020, 32, 465-475. [CrossRef] 
20. Liew, Y.; Kamarudin, H.; Al Bakri, A.M.; Bnhussain, M.; Luqman, M.; Nizar, I.K.; Ruzaidi, C.; Heah, C. Optimization of solids-to-liquid and alkali activator ratios of calcined kaolin geopolymeric powder. Constr. Build. Mater. 2012, 37, $440-451$. [CrossRef]

21. Abdullah, A.; Hussin, K.; Abdullah, M.; Yahya, Z.; Sochacki, W.; Razak, R.; Błoch, K.; Fansuri, H. The Effects of Various Concentrations of $\mathrm{NaOH}$ on the Inter-Particle Gelation of a Fly Ash Geopolymer Aggregate. Materials 2021, 14, 1111. [CrossRef]

22. Aziz, I.H.; Abdullah, M.M.A.B.; Salleh, M.M.; Yoriya, S.; Chaiprapa, J.; Rojviriya, C.; Li, L.Y. Microstructure and porosity evolution of alkali activated slag at various heating temperatures. J. Mater. Res. Technol. 2020, 9, 15894-15907. [CrossRef]

23. Solé, V.; Papillon, E.; Cotte, M.; Walter, P.; Susini, J. A multiplatform code for the analysis of energy-dispersive X-ray fluorescence spectra. Spectrochim. Acta Part B At. Spectrosc. 2007, 62, 63-68. [CrossRef]

24. Dudek, M.; Sitarz, M. Analysis of Changes in the Microstructure of Geopolymer Mortar after Exposure to High Temperatures. Materials 2020, 13, 4263. [CrossRef] [PubMed]

25. Wang, T.; Ishida, T.; Gu, R. A comparison of the specific surface area of fly ash measured by image analysis with conventional methods. Constr. Build. Mater. 2018, 190, 1163-1172. [CrossRef]

26. Aziz, I.H.; Abdullah, M.M.A.B.; Salleh, M.M.; Azimi, E.A.; Chaiprapa, J.; Sandu, A.V. Strength development of solely ground granulated blast furnace slag geopolymers. Constr. Build. Mater. 2020, 250, 118720. [CrossRef]

27. Bai, T.; Song, Z.; Wang, H.; Wu, Y.; Huang, W. Performance evaluation of metakaolin geopolymer modified by different solid wastes. J. Clean. Prod. 2019, 226, 114-121. [CrossRef]

28. Cheng-Yong, H.; Yun-Ming, L.; Abdullah, M.M.A.B.; Hussin, K. Thermal Resistance Variations of Fly Ash Geopolymers: Foaming Responses. Sci. Rep. 2017, 7, srep45355. [CrossRef] [PubMed]

29. Yao, Y.; Wang, Y.; Wei, Q.; Cui, S.; Hao, L. Effect of the Formation of Amorphous Networks on the Structure and Hydration Characteristics of Granulated Blast Furnace Slag. Materials 2020, 13, 1462. [CrossRef] [PubMed]

30. Harech, M.A.; Mesnaoui, M.; Abouliatim, Y.; El Hafiane, Y.; Benhammou, A.; Abourriche, A.; Smith, A.; Nibou, L. Effect of temperature and clay addition on the thermal behavior of phosphate sludge. Bol. Soc. Esp. Cerám. V 2020. [CrossRef]

31. Ahmad, R.; Abdullah, M.; Ibrahim, W.; Hussin, K.; Zaidi, F.A.; Chaiprapa, J.; Wysłocki, J.; Błoch, K.; Nabiałek, M. Role of Sintering Temperature in Production of Nepheline Ceramics-Based Geopolymer with Addition of Ultra-High Molecular Weight Polyethylene. Materials 2021, 14, 1077. [CrossRef]

32. Sabbatini, A.; Pettinari, C.; Sobrados, I.; Rossignol, S.; Vidal, L. Control of shaping and thermal resistance of metakaolin-based geopolymers. Mater. Des. 2017, 116, 374-385. [CrossRef]

33. Sheng, Y.; Hua, Y.; Wang, X.; Zhao, X.; Chen, L.; Zhou, H.; Wang, J.; Berndt, C.C.; Li, W. Application of High-Density Electropulsing to Improve the Performance of Metallic Materials: Mechanisms, Microstructure and Properties. Materials 2018, 11, 185. [CrossRef] [PubMed]

34. Du, Z.-Y.; Lv, Y.-Q.; Han, Y.; Fan, J.-L.; Ye, L. Sintering densification behavior and kinetic mechanism of nano-tungsten powder prepared by sol-spray drying. Tungsten 2020, 2, 371-380. [CrossRef]

35. Sellami, M.; Barre, M.; Toumi, M. Synthesis, thermal properties and electrical conductivity of phosphoric acid-based geopolymer with metakaolin. Appl. Clay Sci. 2019, 180, 105192. [CrossRef] 